\title{
Oyster production and meat yield in Crassostrea spp. (bivalvia: Ostreidae) in Pinar del Rio, Cuba
}

\section{Producción ostrícola y rendimiento en carne de Crassostrea spp. (Bivalvia: Ostreidae) en Pinar del Río, Cuba}

\author{
Abel Betanzos-Vega ${ }^{1}$, Norberto Capetillo-Piñar ${ }^{2}$, Hever Latisnere-Barragán ${ }^{3}$, Nadia Livia Ortiz-Cornejo ${ }^{3}$, \\ José Manuel Mazón-Suástegui i* \\ ${ }^{1}$ Centro de Investigaciones Pesqueras, Calle 246 entre 5ta Ave y Mar, Reparto Barlovento, CP. 19100. Municipio Playa, La \\ Habana, Cuba. \\ ${ }^{2}$ Federación De Sociedades Cooperativas Pesqueras Zona Centro BC Sur. Calle Nayarit, No. 740, Col. Pueblo Nuevo, CP. \\ 23060. La Paz, B.C.S., México. \\ ${ }^{3}$ Centro de Investigaciones Biológicas del Noroeste, S.C. (CIBNOR). Calle I.P.N. 195, Col. Playa Palo de Santa Rita Sur, CP. \\ 23090. La Paz, B.C.S., México. \\ ${ }^{*}$ Corresponding author: jmazon04@cibnor.mx
}

Scientific article received: October 21, 2016 accepted: February 27, 2018

ABSTRACT. The main fishing enterprise located in the province of Pinar del Río, Cuba, markets oyster meat packed in brine bags of $460 \mathrm{~g}$. Oysters come from natural bank fisheries and farms. During the period 2009 - 2013, captures showed an increasing tendency from $50 \mathrm{t}$ to more than $80 \mathrm{t}$. However, the recorded oyster meat yields values from 3.3 - 3.9\% are considered lower than the minimal acceptable value $(4.9 \%)$. The aims of this study were to assess oyster exploitation, meat yield and loss in the final packed product. Monthly and annual variations of meat yield were analyzed regarding capture and oyster size; meanwhile, the meat loss was analyzed by treatments with different proportions of oyster / brine. Significant difference $(p<0.05)$ of meat yield $(\%)$ was observed by oyster species and size with a better performance in farmed oysters. Traditional packing for commercialization (meat / brine, $391 \mathrm{~g} / 69 \mathrm{~g}$, respectively, and total weight of $460 \mathrm{~g}$ ) influenced meat weight loss by leakage of interstitial fluid; this loss was further confirmed by the treatments with different proportions of meat / brine where the 1:1 proportion showed the least meat weight loss. In addition, the non-compliance of management measures regarding commercial size, as well as lack of oyster cleanliness before shell removing process, impacted meat yield analyses during 2009 - 2013.

Key words: Cuba, oyster production, meat yield, Pinar del Rio

RESUMEN. La empresa pesquera de Pinar del Río, Cuba comercializa el ostión desconchado, carne en salmuera, envasada en bolsas de $460 \mathrm{~g}$. Este recurso proviene de bancos naturales y granjas de cultivo. Aunque la captura de 2009 a 2013 incrementó de 50 a más de 80 t, los rendimientos en carne de ostión mostraron valores de 3.3 a 3.9\%, los cuales son inferiores al mínimo aceptable (4.9\%). El objetivo de estudio fue evaluar el aprovechamiento ostrícola, rendimiento en carne y merma en el producto envasado. Se analizó la variación mensual y anual del rendimiento y su relación con la captura y la talla; la merma se analizó mediante tratamientos con diferentes proporciones ostión/salmuera. Se encontraron diferencias significativas $(p<0.05)$ en el rendimiento $(\%)$ en carne según el tipo de ostión y su relación proporcional con la talla, con mayor rendimiento en el ostión de cultivo. La proporción tradicional de comercialización (carne / salmuera, $391 \mathrm{~g} / 69 \mathrm{~g}$, respectivamente; peso total de $460 \mathrm{~g}$ ) incidió en la pérdida de peso en carne por drenaje natural del líquido tisular, corroborado en las pruebas con diferentes proporciones de ostión/salmuera, mostrando menor merma la proporción 1:1. Adicionalmente, el incumplimiento en medidas de manejo, la talla comercial y la falta de limpieza del ostión antes de entregarlo al proceso de desconche pudieron incidir negativamente en el rendimiento en carne durante 2009 - 2013.

Palabras clave: Cuba, producción ostrícola, rendimiento en carne, Pinar del Río 


\section{INTRODUCTION}

In Cuba, oysters are marketed shucked, and their meat is packed into nylon bags containing brine for sale in the domestic market as frozen or fresh products (Frías and Rodríguez 1991). Oyster meat yield $(R)$ has been used as an eco-physiological index (Rebelo et al. 2005), as well as an indicator of industrial efficiency with a minimum acceptable value of 4.9\% (GI 67 2012). Nationally, throughout 2009 - 2013, the average annual oyster (with shell) production reached $1271.3 \mathrm{t}$, of which oyster meat accounted for $73 \mathrm{t}$, resulting in an average yield of $5.7 \%$ regarding total oyster weight delivered to processing facilities for de-shelling and subsequent packaging of meat in brine (ONEI 2015).

In this period, the industrial fishing enterprise EPICOL (located in La Coloma, Pinar del Río province) reported an average annual oyster production of $70.2 \mathrm{t}$, recording the lowest meat yield nationally $(2.5 \mathrm{t}$ of oyster meat $=3.6 \%)$. Currently, oyster meat comes from three "base business units" (UEBs) that supply the resource to EPICOL. Oyster meat is packed in presentations of $460 \mathrm{~g}(\approx 1$ $\mathrm{lb}$ ), consisting of $391 \mathrm{~g}$ of meat and $69 \mathrm{~g}$ of salt solution (brine). During the packaging process, a loss of meat weight from 3.8 to $6.5 \%$ has been observed in two of the three business units. The three UEBs, are dedicated to fishing or oyster farming. The Cortés and Boca de Galafre units, where a loss of meat weight available for commercialization has been reported, maintain their production on both; mangrove oyster fishery (Crassostrea rhizophorae, Guilding 1828) extracted from natural banks and the locally-named, "bottom oyster", which has been phenotypically identified (Betanzos-Vega et al. 2016) as American oyster (Crassostrea virginica, Gmelin 1791). Since both are fished and processed together, no individual statistics is available for each species. Furthermore, because the bottom oyster was just recently included in the fishery (BetanzosVega and Mazón-Suástegui 2014), a commercial size for this species has not been defined yet, and its extraction is based on the minimum legal size es- tablished for the mangrove oyster $(40 \mathrm{~mm})$. Meanwhile, the third unit, the UEB of Morrillo, bases its production on artisanal oyster farming of the $C$. rhizophorae species from wild larvae (seeds) fixed in suspended lines for fattening (Mazón-Suástegui et al. 2011a).

To pinpoint the causes for low productivity of the fished and farmed oysters from Pinar del Río and meat weight loss through packaging until commercialization, the aim of the study was to assess low meat yields throughout 2009 - 2013, analyzing meat yield differences according to oyster species, origin (wild or farming) and size, in each one of the UEBs. In addition, meat weight loss was assessed by an experimental design with different oyster meat and brine proportions.

\section{MATERIALS AND METHODS}

\section{Study area}

The fishing and oyster farming zones assessed in this study are located in the Province Pinar del Río in the westernmost region of Cuba (Figure 1). The oyster-farming business units of Cortés and Boca de Galafre are distributed in the Cortés cove. The UEB of Cortés is located in the watershed of the Cuyaguateje River $\left(22^{\circ} 05.238^{\prime}\right.$ N, 083 58.324' W) whilst Boca de Galafre is located on Bailén beach into the Sábalo estuary and the El Chevi lagoon $\left(22^{\circ} 07.215^{\prime} \mathrm{N}, 083^{\circ} 58.308^{\prime} \mathrm{W}\right)$. The third UEB (Morrillo) is located in Santa Teresa cove $\left(22^{\circ}\right.$ 57.859' N, 083 09.331' W) in Bahía Honda city. Finally, the parent company (EPICOL) is located in the town La Coloma (Figure 1).

\section{Meat yield and oyster production variation}

To determine the impact of fishing and farming oysters regarding meat production, 2009 - 2013 oyster production from the three UEBs was analyzed in EPICOL. To reach this goal, charts were constructed to analyze inter-annual and monthly variability of landed oysters, estimating their respective meat yield after de-shelling, as well as the independent contribution of each UEB. 


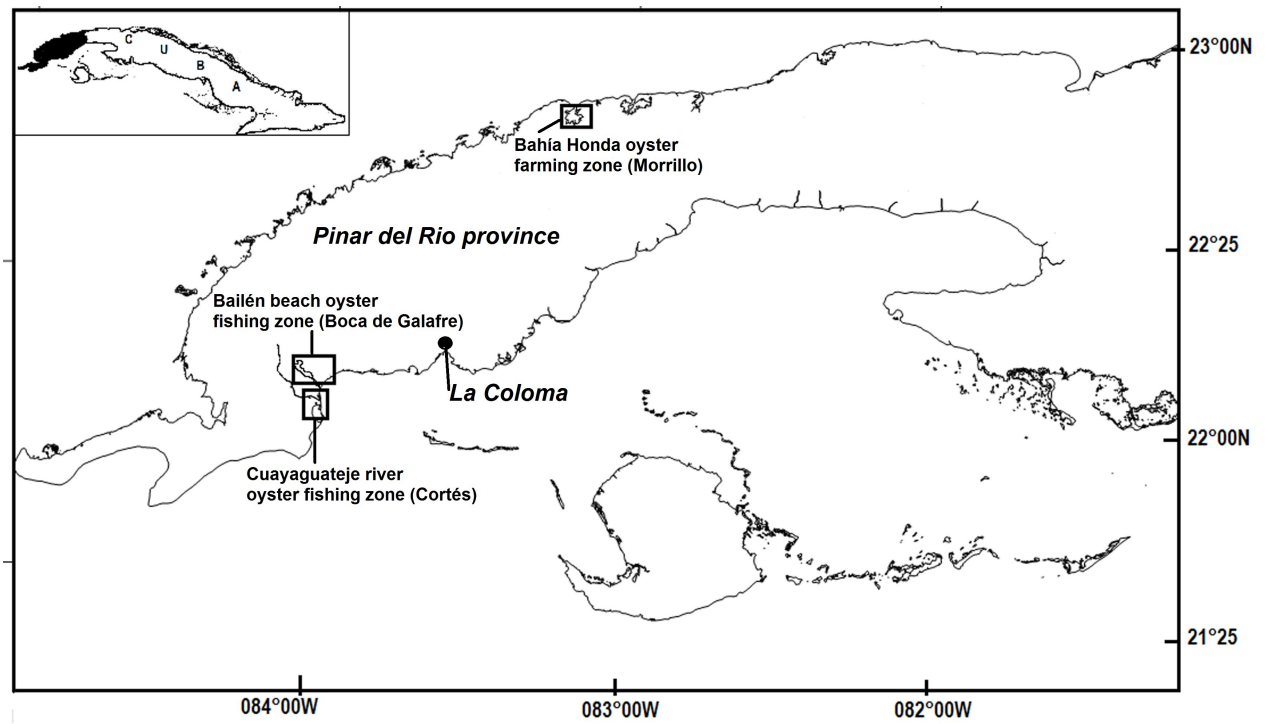

Figure 1. Oyster zones and fishery units assessed (fishing business unit).

\section{Meat yield by oyster species and origin}

The analysis of meat yield differences between oyster species and origin was performed only during January, March and May 2014 carrying out biometrical analyses to the oysters in each of the UEBs ( $\mathrm{n}=100$ to 200 individuals). Before obtaining biometric data, oysters were catalogued by species and origin (wild or farming) and subsequently washed with pressurized sea water to remove sediments, unwanted fauna and other matter. The length of each individual was measured (anteroposterior length) from the umbo to the outer edge of the shell with a Vernier gauge $(0.05 \mathrm{~mm}$ precision). All sampled oysters were de-shelled regardless of size. Total weight (oyster in shell) and meat weight of each individual were determined with a digital balance (Kern EMB600), correctly calibrated and certified by the Instituto Nacional de Investigación en Metrología (INIMET) in Cuba.

The percentage value of meat yield $(R=$ wet weight of oyster meat / oyster weight in shell $x$ $100)$ was calculated according to Lenz and Boehs (2010). The Cuban legislation has defined 4.9\% as the minimal value of meat yield for oysters as a commercial resource, established to ensure a minimally acceptable profitability (GI 67 2012).
The $R$ values were submitted to Bartlett's test of normality. However, since no homoscedasticity of variances was obtained, Kruskal-Wallis test $(p<0.05)$ (Zar 1984) was used to analyze meat yield in each UEB while meat yield variation was calculated in regards to shell length by Pearson's simple linear regression $(p<0.05)$.

\section{Meat weight loss assessment}

To establish a better proportion of oyster meat / brine, two experimental treatments were assayed with the individuals sampled from the Cortés and Boca Galafre UEBs in May 2014. The first treatment $(T 1=391 / 195)$ consisted of $50 \%$ brine weight $(195 \mathrm{~g})$ proportion, relative to the usual weight of the meat $(391 \mathrm{~g})$ while in the second treatment (T2), equal quantities of brine and meat were used (391/391 g). Additionally, the current proportion used by EPICOL (391 g of meat / $69 \mathrm{~g}$ brine) was used as control.

De-shelling and packaging of both oyster species ( $C$. rhizophorae and $C$. virginica) from Cortés and Boca Galafre are carried out in the Galafre facility and subsequently sent to EPICOL. The experiments consisted of sampling 60 bags containing oyster meat, individually marked to track the 


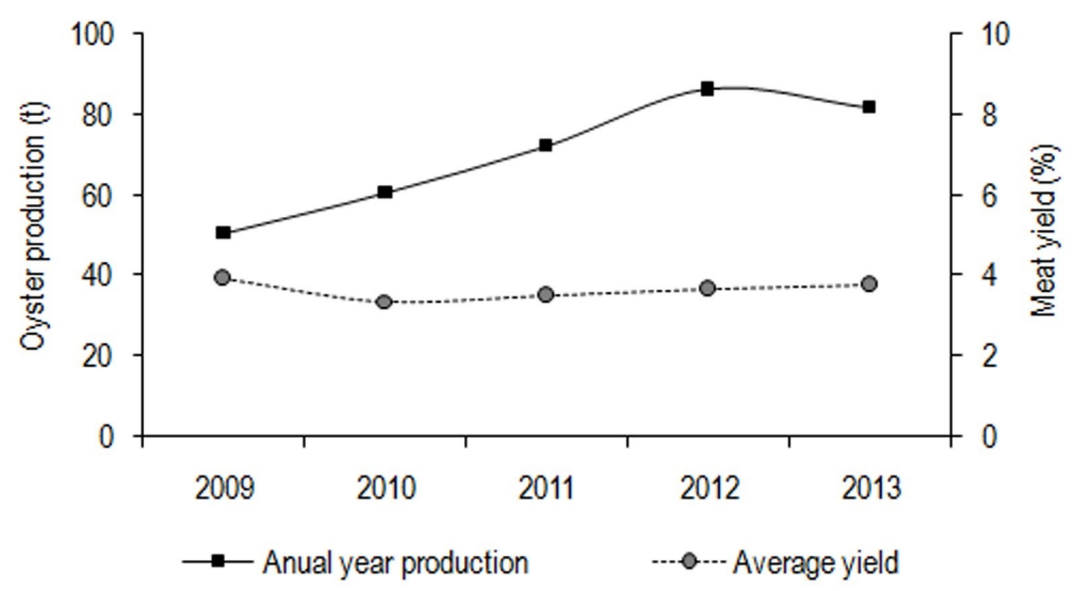

Figure 2. Interannual variation of oyster production volumes and average meat yield during $2009-2013$.

treatment applied (T1, T2 or Control; $n=20$ bags per treatment). The packaging of the samples consisted of weighing both meat and brine in regards to each treatment. All samples (60 bags) were coldstored $\left(4{ }^{\circ} \mathrm{C}\right)$, mixed and transported with the rest of the production, following the usual market chain process until arriving to EPICOL. Once at EPICOL, the meat was removed from the container bags and drained in a suitable sieve for five min to calculate weight loss per bag.

Drained meat weights were used in a one-way ANOVA $(p<0.05)$ to assess differences among treatments, followed by Duncan (1955) test for multiple comparisons.

\section{RESULTS}

The results of the oyster production analysis (2009 - 2013) showed that inter-annual variations in volumes were increasing annually while meat yield did not show the same trend (Figure 2); on the contrary, it showed lower values than the minimal acceptable (4.9\%).

According to the fishing statistics of the period, the Cortés UEB reported an annual average extraction of $6.8 \pm 2.5 \mathrm{t}$ of oysters in shell with an R of $3.4 \%$ while in Boca de Galafre, the annual average extraction was $37 \mathrm{t}$ with an $\mathrm{R}$ of $3.8 \%$ and a total of $27 \mathrm{t}$ with an R of $3.9 \%$ for Morrillo. The historical monthly variation analysis of $\mathrm{R}$ showed the highest values in June and September (Figure 3) although only in June was a value superior to the minimal acceptable achieved. Additionally, during 2009 - 2013, the month of June that showed the highest meat yields did not match that of higher production volumes (Figure 3).

The biometric measurements showed that oysters with larger sizes, as well as those with higher average meat weight, were recorded in Cortés and Boca Galafre, particularly observed in bottom oysters ( $C$. virginica) (Table 1 ). In addition, bottom oysters also showed higher yields compared to wild mangrove oysters, in both sites with significant yield differences $(p<0.05)$ per oyster species (Figure 4$)$. The lowest average sizes were recorded in Morrillo despite these oysters came from farms. Nonetheless, the intraspecific comparison proved that the mangrove oysters farmed in Morrillo had higher meat yield compared to mangrove oysters fished from natural banks.

The regression analysis (Figure 5) showed a positive proportionality between size and yield in the three UEBs. Particularly, in Cortés and Boca de Galafre (Figures 5a and 5b) where both oyster species were included in the analysis, the bottom oyster showed a higher yield value associated to a 


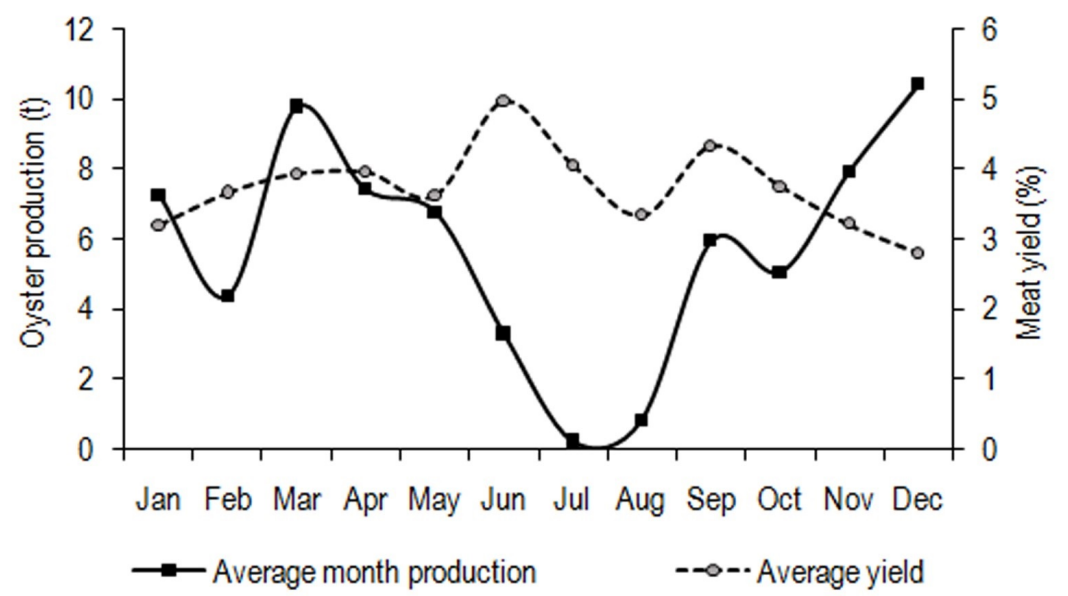

Figure 3. Monthly variability of oyster production and meat yield during $2009-2013$.

Table 1. Biometric data and meat yield $(R)$ of the total number of oysters sampled (Crassostrea sp.) per month and study area.

\begin{tabular}{lccccccccc}
\hline Variable assayed/sites & \multicolumn{3}{c}{ Cortés } & \multicolumn{3}{c}{ Boca de Galafre } & \multicolumn{3}{c}{ Morrillo } \\
\hline 2014 & Jan. & Feb. & May. & Jan. & Feb. & May. & Jan. & Feb. & May. \\
\hline Number of oysters $(\mathrm{n})$ & 150 & 170 & 200 & 150 & 175 & 200 & 100 & 150 & 100 \\
Mean size $(\mathrm{mm})$ & 30.50 & 35.60 & 40.34 & 31.95 & 36.35 & 34.93 & 21.75 & 27.90 & 30.35 \\
Stand. Dev. ( \pm ) & 15.12 & 17.48 & 14.60 & 17.58 & 19.53 & 16.13 & 6.24 & 8.22 & 6.92 \\
Max. size (mm) & 51.25 & 64.50 & 70.85 & 70.10 & 83.20 & 90.50 & 35.60 & 40.90 & 42.65 \\
Min. size (mm) & 6.50 & 7.05 & 9.50 & 7.50 & 5.50 & 8.00 & 6.05 & 7.25 & 8.50 \\
\% commercial size ( $\geq 40 \mathrm{~mm})$ & 20.55 & 34.65 & 47.50 & 23.05 & 38.80 & 30.00 & 0.00 & 7.38 & 10.00 \\
Average gross weight (g) & 29.89 & 36.58 & 37.35 & 31.25 & 39.25 & 38.45 & 15.43 & 17.63 & 18.07 \\
Average meat weight (g) & 1.35 & 1.99 & 1.76 & 1.49 & 2.24 & 1.97 & 0.87 & 1.06 & 1.22 \\
Average R (\%) & 4.52 & 5.44 & 4.71 & 4.77 & 5.71 & 5.12 & 5.64 & 6.01 & 6.75 \\
\hline
\end{tabular}

larger size compared to the mangrove oyster. The $\mathrm{R}$ value $\geq 4.9 \%$ of wild mangrove oyster corresponded to oysters of $\geq 50 \mathrm{~mm}$ in length. Regarding the bottom oyster, $R$ value $\geq 4.9 \%$ was obtained from individuals with size of $\geq 40 \mathrm{~mm}$ in length. Meanwhile, in the UEB of Morrillo (Figure 5c) where total production came from artisanal culturing, the yields obtained were the highest recorded ( $R=6$ and $8 \%)$ from oysters from 30 to $43 \mathrm{~mm}$ in length, which recorded the highest correlation coefficient $\left(r^{2}=\right.$ 0.71 ) between $R$ and shell length.

The analysis of meat weight loss confirmed that it was due to leakage of interstitial fluids showing that an important cause lay on the meat / brine proportion in the commercial presentation. In addition, the results showed that dehydration occurred independently of the origin and species of packaged oyster. The ANOVA showed significant statistical differences among treatments $(F=29.23$; $\mathrm{p}<0.05)$. The second treatment (T2), with a proportion $1: 1$, resulted in higher average meat weight ( $p<0.05)$, and as an outcome, lower weight loss (Table 2). This allowed us to determine that the usual proportion of meat / brine (391 g oyster meat / $69 \mathrm{~g}$ brine) did not result in the expected final meat weight in the commercial product.

\section{DISCUSSION}

Although EPICOL annual oyster production maintained an upward trend from 2009 to 2013, its average annual meat yield was less than $4 \%$, and did not show notable changes along the five years evaluated. Yield variations are determined 


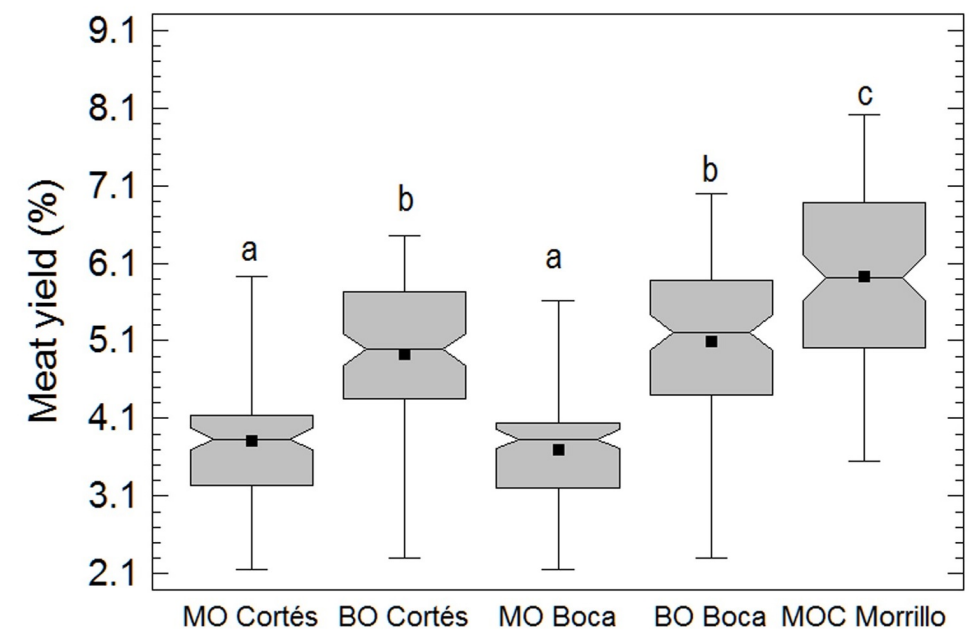

Figure 4. Meat yield during 2009 - 2013 per oyster zone assayed. Mangrove oyster (MO), bottom oyster (BO), mangrove oyster from farming (MOC). Different letters $(a, b, c)$, show statistically different results $(p \leq 0.05)$.

by exogenous and endogenous factors associated to the health of the organisms as well as their reproductive stage, showing maximum yield values in full sexual maturity stages and minimal values during post-spawning stage (George-Zamora et al. 2003, Lenz and Boehs 2010, Mazón-Suástegui et al. 2011b). As reported by Nikolic and Soroa-Bofill (1971), in Cuba two massive reproductive periods of the mangrove-oyster have been determined; one from March - June and another one from September - November, showing maximum sexual maturity in March, June and September. Notoriously, the monthly variation of meat yield showed higher $\mathrm{R}$ value within these months, which strengthens the idea to harvest the resource in those periods of sexual maturity. Therefore, meat yield has been used as an eco-physiological index in oysters (Rebelo et al. 2005).

It is worth highlighting that the different values of meat yield observed during 2009 2013 (lower) and 2014 (higher) could have been attributed to the lack of cleanliness of the oyster shells. The presence of epibiotic organisms, such as juveniles and seeds of the oysters themselves are not de-shelled due to their small size. Even fragments of bark from the roots and branches of the mangroves
(Betanzos-Vega et al. 2014) have caused increase in gross weight of the oysters, which affects the final meat yield values.

In the Cortés and Boca de Galafre facilities, both species of oysters were processed undifferentiated for their commercialization. The fishing commercial size applied for both species has been 40 $\mathrm{mm}$; however, this minimum legal size was determined only for the mangrove oyster (MINAL 2009).

The bottom oyster has been extracted at the same size since there are no relevant fishery studies for this species in the region to determine their population structure by size, available biomass, natural reproductive cycle, closed seasons, or its legal minimal commercial size. The lack of studies is due to the fact that the bottom oyster (C. virginica) has been mistakenly considered as a phenotypic variety of the mangrove oyster ( $C$. rhizophorae), which has adapted to benthic conditions (Betanzos-Vega et al. 2016). For this reason, it has led to the underestimation of its importance as a natural resource and has had repercussions to the oyster production statistics in Pinar del Río. The lack of population studies of $C$. virginica in the region could have impacts on the future of yields in the oyster industry, so it will require a precautionary 

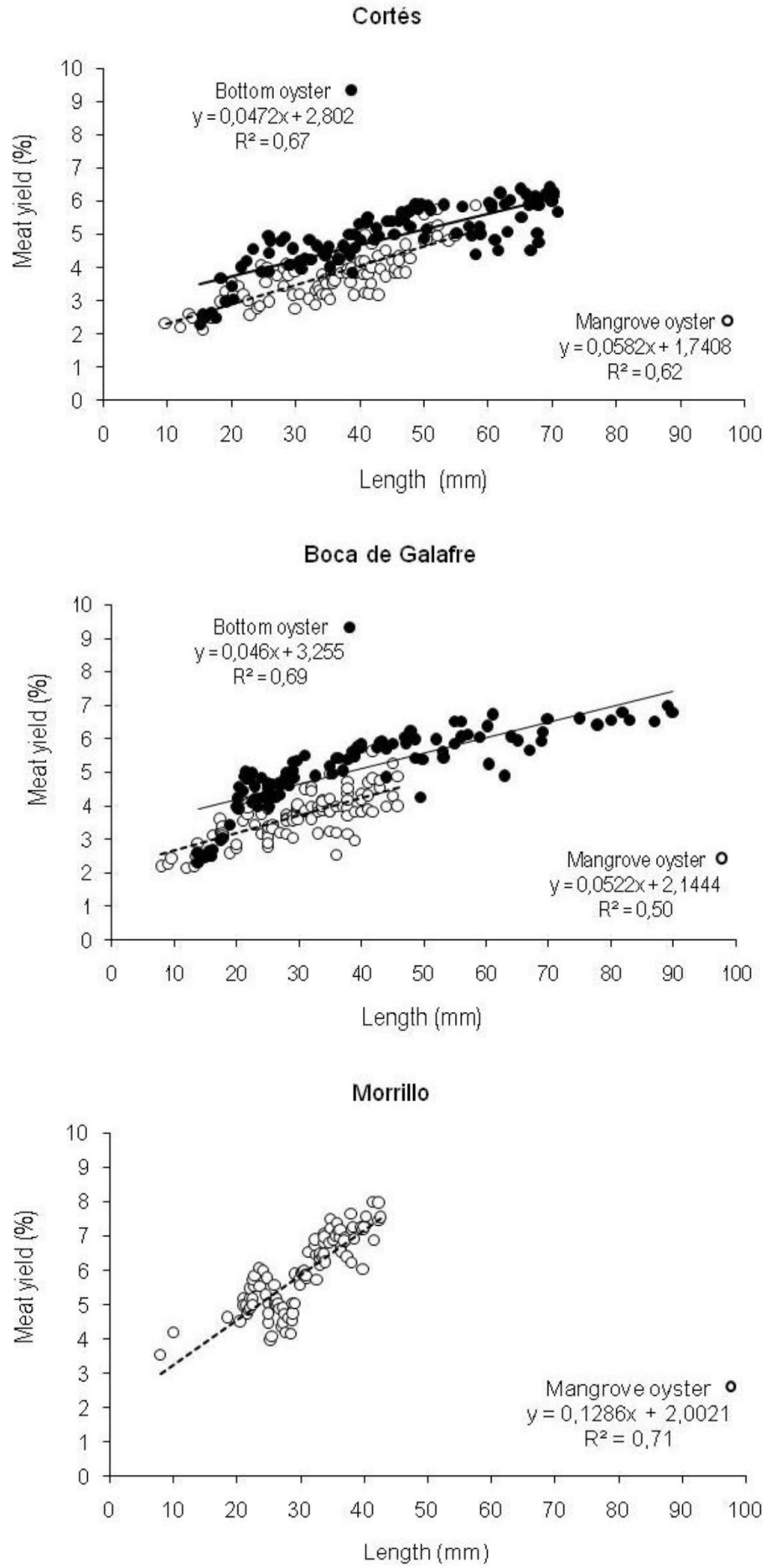

Figure 5. Regression analysis between size (length) and meat yield (\%) of mangrove and bottom oysters in: (a) Cortés UEB; (b) Boca de Galafre UEB and (c) Morrillo UEB. 
Table 2. Final weight of oyster meat and weight loss recorded according to meat / brine proportions.

\begin{tabular}{lcccr}
\hline Indicators & Control & T1 & T2 & \pm SE \\
\hline Meat / brine proportions (g) & $391 / 69$ & $391 / 195$ & $391 / 391$ & \\
Meat initial weight (g) & 391 & 391 & 391 & \\
Meat final weight (g)(mean, g) & $386.64^{a}$ & $387.42^{a}$ & $389.69^{b}$ & $0.29^{*}$ \\
Meat weight loss (mean, g) & $4.36^{a}$ & $3.57^{a}$ & $1.31^{b}$ & $0.29^{*}$ \\
\hline${ }^{a b}$ Different letters on the same row are statistically different $(\mathrm{p}<0.05$, Dun- \\
can).
\end{tabular}

extraction approach (FAO 1996) to achieve a sustainable exploitation of this resource.

The analysis of average annual volume of landings of each UEB showed higher extracted biomass at Boca de Galafre. However, the highest meat yield was recorded from farmed oysters in the Morrillo UEB. This study allowed us to determine that oyster fishing and processing of a size lower than the legal minimum ( $40 \mathrm{~mm}$ ) affect the $R$ value since a proportional relationship exists between shell length and total and meat weights of the organism (Hernández et al. 1998, Lenz and Boehs 2010), as it was confirmed by the analysis of lengths against meat yield. Despite the average gross weight and meat weight were higher in the oysters caught in Cortés and Boca de Galafre - perhaps because of the inclusion of $C$. virginica in the catching, higher values of meat yield ( 6 to $8 \%$ ) were obtained from the mangrove oysters farmed in Morrillo although just $10 \%$ of the oysters were commercial size. The higher yields observed relate to phenotypic characteristics since the shell of farmed oysters are thinner (less weight) and the inferior valve (left valve) shows a strong concavity that allows a higher growth in soft tissues of the organism, an increase in weight and hence a higher percentage in value estimation. In addition, as it has been previously reported, meat yield of farmed oysters, as well as their nutritional benefits, is higher than that of wild oysters (Sáenz 1965, Milano et al. 2006).

Regardless of the assessed factors that influenced yield variations, several human errors that affected the yields recorded were observed during the study. Some of these errors included: (1) extraction of organisms that did not reach commercial size (less than $40 \mathrm{~mm}$ ); (2) presence of young oysters attached to the shell of adults and, (3) lack of cleanliness of organisms delivered for processing. This last issue is important since payment to fishermen depends entirely on total oyster weight (oyster in shell) delivered to the UEB facilities. The presence of epibiotic fauna and unwanted material increases gross weight of oysters, but they affect meat yield, which has been particularly observed in bottom oysters since they are always underwater (Núñez et al. 2010).

The wild oyster fishery, with commercial goals, generates a bigger instability in oyster production because it depends on the extant biomass in natural banks, which are generally submitted to high-fishing and natural environmental variations of the shorelines. However, artisanal oyster farming has proven to generate higher yields if based on integral management of the resource and performed in suitable sites (Lodeiros-Seijo and Freites-Valbuena 2008). The encouragement of oyster aquaculture would guarantee a higher sustainable production and profitability for the region (Betanzos-Vega et al. 2014).

Concerning meat weight decrease in the commercial product, the traditional proportion of meat / brine has given rise to a natural leakage of interstitial fluids in the packed meat because part of it remains uncovered by the brine. The experimental treatments gave clear results for determining the best proportion of meat / brine (T2, proportion 1:1) to avoid weight loss in the final product. These results are being considered in EPICOL management plans for their application. Finally, it is of paramount importance to follow the regulations of minimum size for commercialization of fished oysters, carry out a thorough cleaning of 


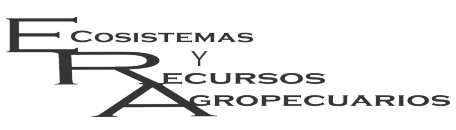

Betanzos-Vega et al.

Oyster production and meat yield, Cuba

Ecosist. Recur. Agropec.

5(15):501-510,2018

the oysters before delivery for the de-shelling process and ensure the correct weight in the processing for the best estimation of oyster meat yields.

\section{CONCLUSIONS}

Despite the tendency of annual increase in capture volumes during 2009 - 2013, meat yields did not reach the minimum acceptable by the industry $(4.9 \%)$. The analysis of monthly catch variation, highlighted the bad practices of fishery management. Months of maximum sexual maturity and spawning were not taken into account to increase or decrease the catch, as a function of these biological parameters. These results suggest the need of reproductive and biomass studies for the establishment of bans during the maximum spawning stage to avoid low yields, as well as to protect seed recruitment and establish a maximum sustainable catch per species. Regardless of the proportional relationship between oyster size and meat yield, the cultivated oysters produced in Morrillo UEB showed a higher performance in spite of its smaller size, which highlights the importance of introducing artisanal oyster aquaculture techniques in the facilities of Cortés and Boca de Galafre. Given that bottom oyster (C. virginica) has shown a higher size and meat yield than the mangrove oyster ( $C$. rhizophoroae) in Cortés and Boca Galafre, it can be considered a better candidate for oyster aquaculture in the region by seed production in laboratory. Regarding the proportion of meat / brine, it was observed that the $1: 1$ proportion showed less weight loss by increasing meat yield in the final product, so it should be applied.

\section{ACKNOWLEDGEMENTS}

The authors would like to thank the fisheries and quality control technical staff of EPICOL, Cuba: Rodaimy Pérez and Israel Trujillo; technical support of CIBNOR staff: Delfino Barajas, Pablo Ormart and Guillermo García. This study was partially funded by Sectoral Research Fund for Education and CIBNOR projects: CONACYTCB 258282, PROINNOVA-CONACYT/PEASA, 221894, 230265, and 241777 under the academic direction of JMMS; Diana Fischer helped with editorial services.

\section{LITERATURE CITED}

Betanzos-Vega A, Mazón-Suástegui JM (2014) Hidrodinámica y producción de ostión de la laguna El Chevi, sur de Pinar del Río, Cuba. Revista Cubana de Investigaciones Pesqueras 31: 45-57.

Betanzos-Vega A, Rivero-Suárez S, Mazón-Suástegui JM (2014) Factibilidad económico-ambiental para el cultivo sostenible de ostión de mangle Crassostrea rhizophorae (Guilding 1828), en Cuba. Latin American Journal of Aquatic Research 42: 1148-1158.

Betanzos-Vega A, Lodeiros C, Espinosa-Sáez J, Mazón-Suástegui JM (2016) Identificación de la ostra Americana Crassostrea virginica como recurso natural en las Islas del Caribe: Cuba. Revista Mexicana de Biodiversidad 87: 1342-1347

Duncan DB (1955) Multiple range and multiple F tests. Biometrics 11: 1-42.

FAO (1996) Precautionary approach to capture fisheries and species introductions. FAO Technical Guidelines for Responsible Fisheries. No. 2. Rome, FAO, 54 p. http://www.fao.org/3/a-w3592e.pdf. Consulted: 19 May, 2016

Frías JA, Rodríguez J (1991) Oyster culture in Cuba: Current state, techniques and industry organization. In: Newkirk GF, Field BA (Eds). Oyster culture in the Caribbean. Proceeding of a Workshop. Kingston, Jamaica. Mollusc Culture Network, Halifax, Canada. pp. 51-74. 
George-Zamora A, Sevilla-Hernández ML, Aldana-Aranda D (2003) Ciclo gonádico del ostión americano Crassostrea virginica (Lamellibranchia: Ostreidae) en Mecoacán, Tabasco, México. Revista Biología Tropical 51 Suplemento 4: 109-117.

GI 67(2012) Actualización de los indicadores de eficiencia industrial de las producciones pesqueras del Grupo Empresarial de la Industria Alimentaria. Procedimiento Operativo. Dirección Productiva Pesquera, Grupo de Industria, Ministerio de la Industria Alimentaria. Cuba. 4p.

Hernández O, Troccoli L, Millán J (1998) Crecimiento, engorde y sobrevivencia de la ostra de mangle Crassostrea rhizophorae (Guilding, 1828) en la Isla de Cubagüa, Venezuela. Caribbean Journal of Science 34: 243-249.

Lenz T, Boehs G (2010) Ciclo reproductivo del ostión de manglar Crassostrea rhizophorae (Bivalvia: Ostreidae) en la Bahía de Camamu, Bahia, Brasil. Revista de Biología Tropical 59: 137-149.

Lodeiros-Seijo C, Freites-Valbuena L (2008) Estado actual y perspectivas del cultivo de moluscos bivalvos en Venezuela. En: Lovatelli A, Farías A, Uriarte I (Eds). Estado actual del cultivo y manejo de moluscos bivalvos y su proyección futura: factores. pp. 135-150.

Mazón-Suástegui JM, Avilés-Quevedo MA, Rivero-Suárez S (2011a) Bases tecnológicas para el cultivo sostenible del ostión nativo Crassostrea rhizophorae, en el ecosistema sabana Camagüey, República de Cuba. Manual Técnico, Proyecto Piloto para el Cultivo de Ostión, GEF/PNUD, protección al ecosistema Sabana-Camagüey. 69p.

Mazón-Suástegui JM, Ruíz-García MC, Chávez-Villalba J, Rodríguez-Jaramillo C, Saucedo, PE (2011b) Analysis of growth and first reproduction of hatchery-reared juvenile Cortez oyster (Crassostrea corteziensis) in northwestern México: Proposal of a minimal fishing size. Aquaculture Research 42: 1558-1568.

Milano J, Armas HD, Salazar G (2006) Perfil de ácidos grasos de Crassostrea rhizophorae proveniente de las lagunas de Chacopata y la Restinga (Venezuela) y el Pantano de Caroní (Trinidad y Tobago). Ciencias Marinas 32: 1-11.

MINAL (2009) Tallas mínimas para especies marinas comerciales. Resolución No. 126/2009 del Ministerio de la Industria Alimentaria. 7p.

Nikolic M, Soroa-Boffill J (1971) El ostión de mangle Crassostrea rhizophorae, Guilding, 1828. Algunas observaciones sobre sus dimensiones, pesos y sexos. FAO. Roma. 220p.

Núñez M, Lodeiros C, Ramirez E, Narváez N, Graziani C (2010) Crecimiento y sobrevivencia de la ostra de mangle Crassostrea rhizophorae bajo condición de cultivo intermareal y submareal. Zootecnia Tropical 28: $239-254$.

ONEI (2015) Panorama Económico y social. Cuba 2014. Oficina Nacional de Estadística e Información de la República de Cuba. http://www.onei.cu/panorama2014.htm. Date consulted: 24 april, 2016.

Rebelo MF, Amaral MCR, Pfeiffer WC (2005) Oyster condition index in Crassostrea rhizophorae (Guilding, 1828) from a heavy-metal polluted coastal lagoon. Brazilian Journal of Biology 2: 345-351.

Sáenz BA (1965) El ostión antillano Crassostrea rhizophorae, Guilding y su cultivo experimental en Cuba. Instituto Nacional de la Pesca. Nota sobre Investigaciones 7: 1-32.

Zar J (1984) Biostatistical analysis. 2nd Edition. Prentice- Hall. New Jersey. 120p. 